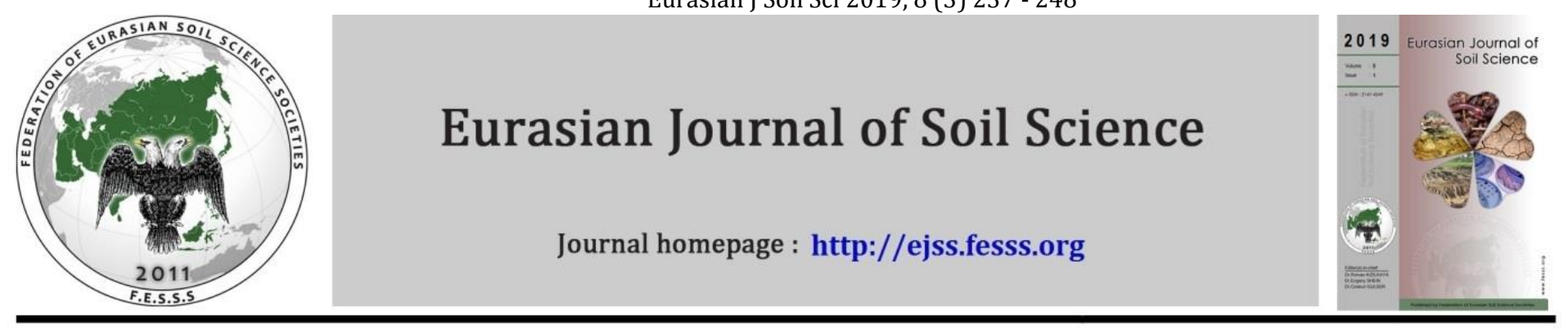

\title{
Soil fertility assessment and mapping spatial distribution of Agricultural Research Station, Bijayanagar, Jumla, Nepal
}

\author{
Dinesh Khadka a,*, Sushil Lamichhane a, Rita Amgain a, Sushila Joshi a, \\ Shree P. Vista b, Kamal Sah a, Netra H. Ghimire b
}

a Soil Science Division, NARC, Khumaltar, Lalitpur, Nepal

${ }^{\mathrm{b}}$ Agricultural Research Station, NARC, Bijayanagar, Jumla, Nepal

\section{Article Info}

Received : 27.10.2018

Accepted : 13.05.2019

\begin{abstract}
Knowledge about the soil fertility status and mapping their spatial distribution play a crucial role for sustainable planning of particular area. Thus, a study was conducted to assess the soil fertility status of the Agricultural Research Station, Bijayanagar, Jumla, Nepal. The farm is situated at the latitude $29.273656^{\circ} \mathrm{N}$ and longitude $82.180967^{\circ} \mathrm{E}$ as well altitude 2370 masl. The total 18 samples were collected randomly at a depth of $0-20 \mathrm{~cm}$ by using soil sampling auger. A GPS device was used for determination of geographical position of soil sampling points. The collected samples were analyzed following standard analytical methods in the laboratory of Soil Science Division, Khumaltar. The Arc-GIS 10.1 software was used for the soil fertility distribution mapping. The observed data revealed the structure was sub-angular blocky, whereas colour were dark grayish brown and very dark brown. The sand, silt and clay content were ranged $27-47 \%, 33.10-61.10 \%$ and $11.90-23.90 \%$, respectively and categorized loam and silt loam in texture. The soil pH was moderately acidic to moderately alkaline (5.45-7.66) and very low in available boron (0.01-0.28 mg/kg) and sulphur (0.59-6.23 mg/kg). Moreover, very low to very high available iron (15.90-300.50 mg/kg), very low to high available manganese (1.46-12.88) and low to high organic matter (2.07-6.53\%). Similarly, medium to high total nitrogen (0.14-0.23\%), available potassium $(40-255 \mathrm{mg} / \mathrm{kg})$ and zinc $(1.12-8.26 \mathrm{mg} / \mathrm{kg})$. Correspondingly, high available calcium $(1632-2880 \mathrm{mg} / \mathrm{kg})$ and magnesium $(98-456$ $\mathrm{mg} / \mathrm{kg})$, and very high available phosphorus $(64.2-257.2 \mathrm{mg} / \mathrm{kg})$ and copper $(2.58-12.16$ $\mathrm{mg} / \mathrm{kg}$ ). The determined soil test data can be used for sustainable soil management as well as developing future research strategy in the farm.
\end{abstract}

Keywords: ARS, Jumla, ordinary kriging, soil fertility maps, soil testing, sustainable soil management.

(C) 2019 Federation of Eurasian Soil Science Societies. All rights reserved

\section{Introduction}

Soil is an important natural dynamic body to give life to all living things in the World (Jones, 2012). Fertile and productive soil proliferate life whereas, unfertile and unproductive soil brings hunger and famines. Soil fertility mangement have great challenge now days because of various intrinsic and extrinsic factors. In Nepal, people do not think about the sustainable management of soil for long-term benefit, while people only think for short-term benefit. During crop growth they do not think about how much element present in the soil, and how much amount should have to apply. In most of the sites of Nepal, soil organic matter is in extremely critical as well very acidic due to unmanaged farming (Khadka et al., 2016, 2017, 2018).

The soil fertility evaluation is the most basic decision making tool in order to efficient plan of a particular land use system (Havlin et al., 2010). There are several techniques for the evaluation of soil fertility status.

\footnotetext{
${ }^{*}$ Corresponding author.

Soil Science Division, NARC, Khumaltar, Lalitpur, Nepal

Tel.: +977 015521149

e-ISSN: 2147-4249
}

E-mail address: dinesh.khadka92@gmail.com DOI: 10.18393/ejss.566551 
Among them soil testing is a most popular everywhere, as well as more appropriate also. Soil testing provides information regarding nutrient availability in soils which forms the basis for the fertilizer recommendations for economic production of crops. Soil analysis includes physical properties (texture, structure, colour, bulk density etc.) and chemical properties (soil pH, organic matter, macro and micronutrients etc.), which symbolize prerequisite for sustainable soil management (Panda, 2010). Among them some physical parameters can be determined in the field, while most of the chemical parameters should have to analyze in the laboratory.

Soil properties vary spatially from a small to larger area might be due to effect of intrinsic (parent materials and climate) and extrinsic factors such as soil management practices, indigenous fertility status, crop rotation and nature of standing crop (Cambardella and Karlen, 1999). Describing the spatial variability of soil fertility across a field has been difficult until new technologies such as Global Positioning Systems (GPS) and Geographic Information Systems (GIS) were introduced. Collection of soil samples by using GPS is very important for preparing thematic soil fertility maps (Mishra et al., 2013). Similarly, Geographical Information System (GIS) is a potential tool used for easy access, retrieval and manipulation of voluminous data of natural resources often difficult to handle manually. It facilitates manipulation of spatial and attributes data useful for handling multiple data of diverse origin (Mandal and Sharma, 2009). Based on the geo-statistical analysis, several studies have been conducted to characterize the spatial variability of different soil properties (Huang et al., 2007; Weindorf and Zhu, 2010; Liu et al., 2013). Among the different geo-statistical methods, ordinary kriging is widely used to map spatial variation of soil fertility because it provides a higher level of prediction accuracy (Song et al., 2013).

Nepal Agricultural Research Council (NARC) was established to strengthen agriculture sector in the country through agriculture research. Agricultural Research Station, Bijayanagar, Jumla is an important wing among the research farms of NARC, in order to generate appropriate agriculture production technologies for western high hills of Nepal. This area is also the most food insecure site of Nepal (Acharya et al., 2018). However, Information on soil fertility status and mapping their spatial distribution for Agricultural Research Station, Bijayanagar, Jumla are not done yet. Therefore, it is important to investigate the soil fertility status and mapping their spatial distribution, thus may provide valuable information relating agricultural research strategy development. Considering this, the present study was initiated with the objective to assess the soil fertility status as well as their spatial distribution in the Agricultural Research Station, Bijanagar, Jumla, Nepal.

\section{Material and Methods}

\section{Study Area}

The study was carried out at Agricultural Research Station, Bijaynagar, Jumla, Nepal (Figure 1). The research station is located within the latitude $29.271627^{\circ} \mathrm{N}$ to $29.273656^{\circ} \mathrm{N}$ and longitude $82.179565^{\circ} \mathrm{E}$ to $82.180967^{\circ} \mathrm{E}$ as well altitude 2337 masl to 2370 masl. The farm is situated in the headquarter of Jumla district as well on the way of Karnali highway (Surkhet-Jumla road). The average temperature varies from $18^{\circ} \mathrm{C}$ to $30^{\circ} \mathrm{C}$ in summer and $-14^{\circ} \mathrm{C}$ to $8^{\circ} \mathrm{C}$ in winter and the annual average rainfall is $1343 \mathrm{~mm}$. Rice, wheat, maize, barley, bean, buckwheat, amaranthus and millets are the major crops grown in the farm (ARS, 2017).

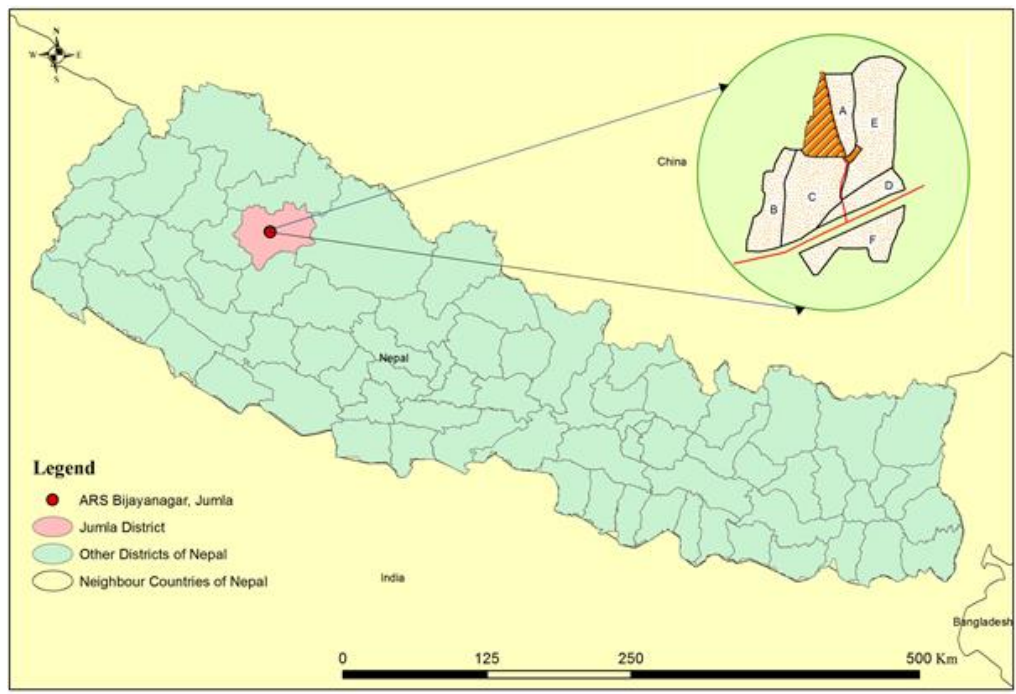

Figure 1. Location Map of Agricultural Research Station, Bijyanagar, Jumla, Nepal 


\section{Soil Sampling}

Surface soil samples (0-20 cm depth) were collected from different sites of Agricultural Research Station, Bijaynagar, Jumla, Nepal during April 2017. The total 18 soil samples were collected from the research farm by using soil sampling auger (Figure 2). The exact locations of the samples were recorded using a handheld GPS receiver. The random method based on the variability of the land was used to collect soil samples.

\section{Laboratory Analysis}

The collected soil samples were analyzed at laboratory of Soil Science Division, Khumaltar. The different soil parameters tested as well as methods adopted to analyze is shown on the Table 1.

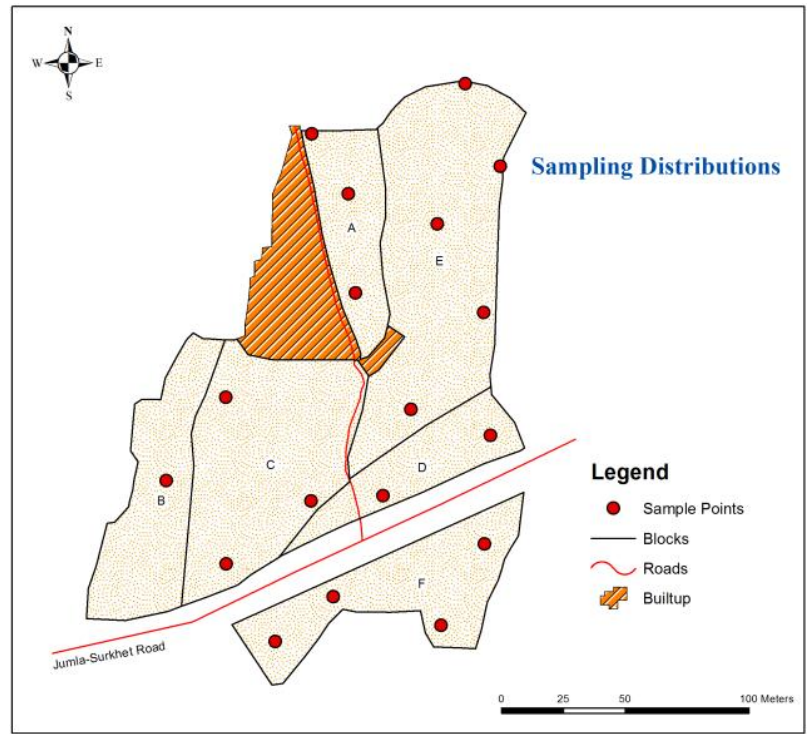

Figure 2. Soil sample distribution during soil sampling in the study area

Table 1. Parameters and methods adopted for the laboratory analysis at Soil Science Division, Khumaltar

\begin{tabular}{|c|c|c|c|}
\hline & Parameters & Unit & Methods \\
\hline \multirow{4}{*}{$\frac{\overrightarrow{0}}{\stackrel{0}{n}}$} & Soil texture & & Hydrometer (Bouyoucos, 1927) \\
\hline & Soil colour & & Munshell-colour chart (Munsell, 2009) \\
\hline & Soil structure & & Field-feel \\
\hline & Bulk Density & & Core (Keen and Raczkowaski, 1921) \\
\hline \multirow{9}{*}{ 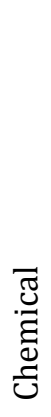 } & Soil pH & & Potentiometric 1:2 (Jackson, 1973) \\
\hline & Organic matter & $\%$ & Walkely and Black (Walkley and Black, 1934) \\
\hline & Total N & $\%$ & Kjeldahl (Bremner and Mulvaney, 1982) \\
\hline & Available $\mathrm{P}_{2} \mathrm{O}_{5}$ & $\mathrm{mg} / \mathrm{kg}$ & Olsen's (Olsen et al., 1954) \\
\hline & Available $\mathrm{K}_{2} \mathrm{O}$ & $\mathrm{mg} / \mathrm{kg}$ & Ammonium acetate (Jackson, 1967) \\
\hline & Available $\mathrm{Ca}, \mathrm{Mg}$ & $\mathrm{mg} / \mathrm{kg}$ & EDTA Titration (El Mahi et al., 1987) \\
\hline & Available S & $\mathrm{mg} / \mathrm{kg}$ & Turbidimetric (Verma et al., 1977) \\
\hline & Available B & $\mathrm{mg} / \mathrm{kg}$ & Hot water (Berger and Truog, 1939) \\
\hline & Available Fe, Zn, Cu, Mn & $\mathrm{mg} / \mathrm{kg}$ & DTPA (Lindsay and Norvell, 1978) \\
\hline
\end{tabular}

\section{Statistical Analysis}

Descriptive statistics (mean, range, standard deviation, standard error, coefficient of variation) of soil parameters were computed using the Minitab 17 package. Rating (very low, low, medium, high and very high) of determined values were based on Soil Science Division, Khumaltar. The coefficient of variation was also ranked for determination of nutrient variability according to the procedure of (Aweto, 1982) where, CV $\leq 25 \%=$ low variation, $\mathrm{CV}>25 \leq 50 \%=$ moderate variation, $\mathrm{CV}>50 \%=$ high variation. Arc Map 10.1 with geostatistical analyst extension of Arc GIS software was used to prepare spatial distribution map of soil parameters, while interpolation method employed was ordinary kriging with stable semi-variogram. Similarly, the nutrient index was also determined by the formula given by Ramamoorthy and Bajaj (1969).

Nutrient index (N.I.) $=\left(\mathrm{N}_{\mathrm{L}} \times 1+\mathrm{N}_{\mathrm{M}} \times 2+\mathrm{N}_{\mathrm{H}} \times 3\right) / \mathrm{N}_{\mathrm{T}}$

Where, $\mathrm{N}_{\mathrm{L}}, \mathrm{N}_{\mathrm{M}}$ and $\mathrm{N}_{\mathrm{H}}$ are number of samples falling in low, medium and high classes of nutrient status, respectively and $\mathrm{N}_{\mathrm{T}}$ is total number of samples analyzed for a given area. Similarly, interpretation was done as value given by Ramamoorthy and Bajaj (1969) shown on the Table 2.

Table 2. Rating Chart of Nutrient index

\begin{tabular}{ll}
\hline Nutrient Index & Value \\
\hline Low & $<1.67$ \\
Medium & $1.67-2.33$ \\
High & $>2.33$ \\
\hline
\end{tabular}




\section{Results and Discussion}

The soil fertility distribution of the studied site was assessed with respect to texture, colour, structure, bulk density, $\mathrm{pH}$, organic matter, primary nutrients, secondary nutrients and micronutrients such as $\mathrm{B}, \mathrm{Fe}, \mathrm{Zn}, \mathrm{Cu}$, and $\mathrm{Mn}$, and the results obtained are presented and discussed in the following headings.

\section{Soil Texture}

Soil texture plays important role for drainage, water holding capacity, aeration, susceptibility to erosion, organic matter content, cation exchange capacity, pH buffering capacity and soil tilth (Berry et al., 2007). The sand content of samples ranged from 27 to $47 \%$ with a mean of $33.98 \%$ and that of silt content were 33.10 to $61.10 \%$ with a mean of $47.12 \%$, while the range of clay content was 11.9 to $23.9 \%$ with a mean of $18.91 \%$ (Table 3 ). This shows loam and silt loam soil texture, where distribution of loam texture is dominant (Figure 3). The loam soil inhabiting site is good for cultivation various kinds of crops, while in silt loam site care should be taken for tillage and water managment. The coefficients of variation between the soil samples were low for sand (12.14\%), silt $(13.06 \%)$ and clay $(21.62 \%)$.

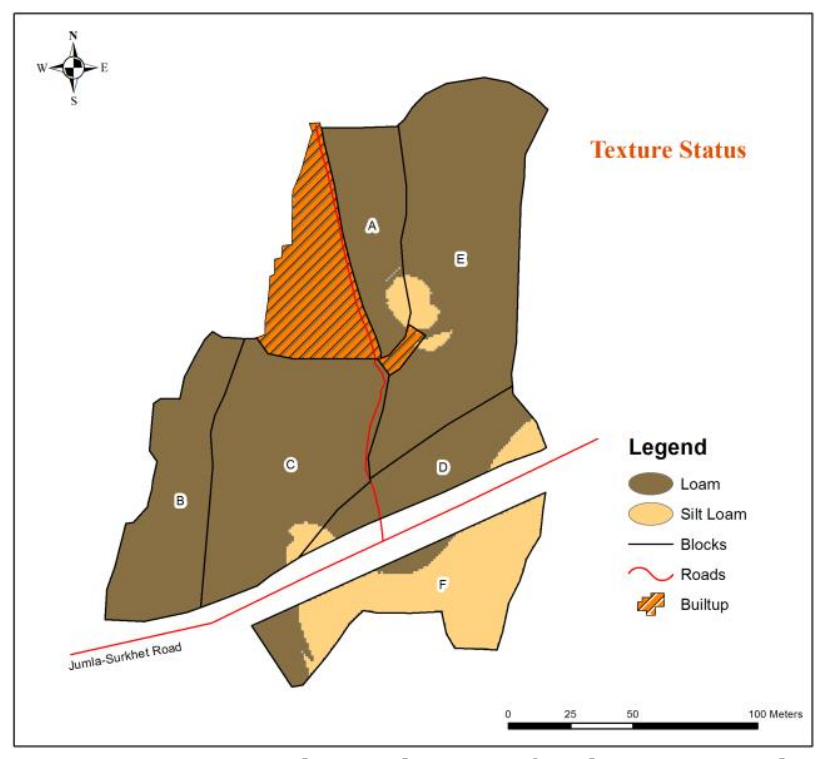

Figure 3. Spatial Distribution of Soil Texture in the Agricultural Research Station, Bijayanagar, Jumla, Nepal

Table 3. Soil Texture Status of Agricultural Research Station, Bijayanagar, Jumla, Nepal

\begin{tabular}{lccc}
\hline Descriptive & \multicolumn{3}{c}{ Soil separates } \\
\cline { 2 - 4 } Statistics & Sand, \% & Silt, \% & Clay, \% \\
\hline Mean & 33.98 & 47.12 & 18.91 \\
SEM & 0.97 & 1.45 & 0.96 \\
SD & 4.12 & 6.15 & 4.09 \\
Minimum & 27 & 33.1 & 11.9 \\
Maximum & 47 & 61.1 & 23.9 \\
CV\% & 12.14 & 13.06 & 21.62 \\
Class & & Loam; Silt Loam & \\
\hline
\end{tabular}

$\mathrm{SEM}=$ Standard error of the mean; $\mathrm{SD}=$ Standard deviation

\section{Soil Colour}

Colour is most noticeable properties of soil that gives clues about the nature of the root zone (Baumann et al., 2016). Two kinds of soil colour; dark grayish brown (10YR 4/2) and very dark brown (10YR 3/2) were observed in the studied sites. The observed colour denotes optimum amount of humus in the soil.

\section{Soil Structure}

Soil structure refers to the pattern of spatial arrangement of soil particles in a soil mass (Brady and Weil, 2004). The sub-angular blocky kind of structure was observed in all the sites. The observed soil structure is good for agriculture point of view because in such structure soil aggregates are separated by elongated continuous pores, which allows good water and nutrient movement, and facilitates root growth (Pagliai and Vignozzi, 2002).

\section{Bulk Density}

Soil bulk density is a basic dynamic soil property that influenced by various physical and chemical properties (Chaudhari et al., 2013). The bulk density ranged from $1.16-1.20 \mathrm{~g} / \mathrm{cm}^{3}$ with a mean of $1.18 \mathrm{~g} / \mathrm{cm}^{3}$. This shows the bulk density is ideal for the plants growth. The satisfactory conditions of organic matter as well as fine texture might be the cause of ideal bulk density in the farm. The optimum condition of bulk density indicates less compaction inside the soil system, which helps to make water and nutrient movement easier; hence root growth also becomes easier. 


\section{Soil pH}

Soil $\mathrm{pH}$ is one of the most important characteristics of soil fertility, because it has a direct impact on nutrient availability and plant growth (Brady and Weil, 2002). The soil $\mathrm{pH}$ varied from 5.45 to 7.66 with a mean of 6.54 (Table 4). The distribution soil pH varied from moderately acidic to moderately alkaline, but majority area contained nearly neutral (6.5-7.0) range (Figure 4 ). The variation on the soil management practice as well as crop allocation in the different sites of the farm from the longer period of time might be the cause the high variation of soil $\mathrm{pH}$ (moderately acidic to moderately alkaline). High acidity in the soil reduces most of the nutrient availability, as well as directly affects root structure also (Havlin et al., 2010). Application of agricultural lime in the acidic inhibiting site as shown in the figure 4 is important for their amelioration. Soil $\mathrm{pH}$ showed low variability $(10.02 \%)$ among the soil samples.

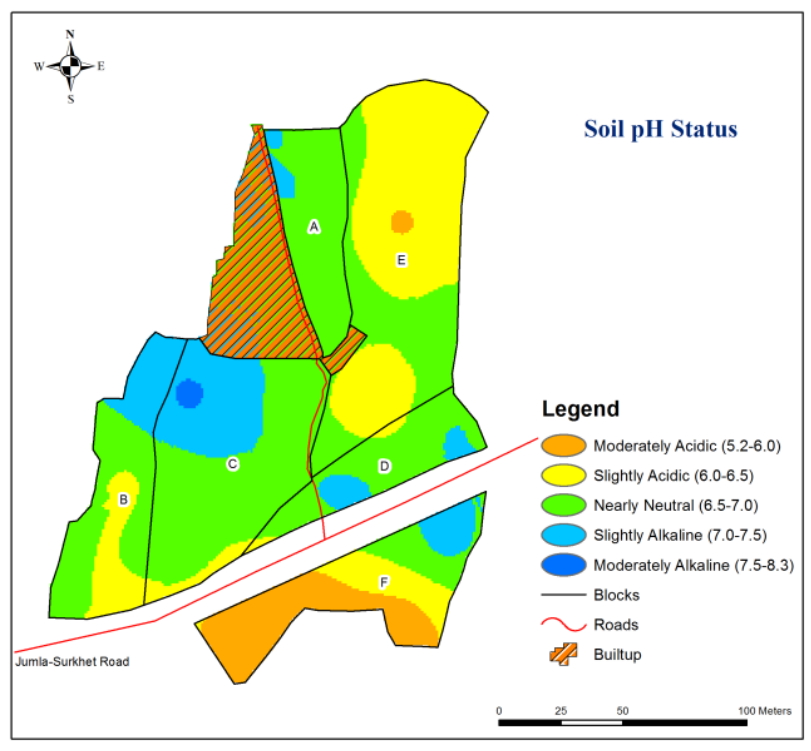

Figure 4. Spatial Distribution of Soil pH in the Agricultural Research Station, Bijayanagar, Jumla, Nepal

Table 4. Soil fertility status of agricultural research station, Bijayanagar, Jumla, Nepal

\begin{tabular}{lccccc}
\hline Descriptive & \multicolumn{4}{c}{ Soil Fertility Parameters } \\
\cline { 2 - 6 } Statistics & $\mathrm{pH}$ & $\mathrm{OM}, \%$ & $\mathrm{~N}, \%$ & $\mathrm{P}_{2} \mathrm{O}_{5}, \mathrm{mg} / \mathrm{kg}$ & $\mathrm{K} 2 \mathrm{O}, \mathrm{mg} / \mathrm{kg}$ \\
\hline Mean & 6.54 & 4.20 & 0.16 & 144.00 & 131.30 \\
SEM & 0.15 & 0.29 & 0.01 & 11.40 & 12.80 \\
SD & 0.66 & 1.21 & 0.04 & 48.40 & 54.50 \\
Minimum & 5.45 & 2.07 & 0.10 & 64.20 & 40.40 \\
Maximum & 7.66 & 6.53 & 0.23 & 257.20 & 255.20 \\
CV\% & 10.02 & 28.80 & 21.81 & 33.64 & 41.52 \\
\hline
\end{tabular}

$\mathrm{SEM}=$ Standard error of the mean; $\mathrm{SD}=$ Standard deviation

\section{Organic Matter}

Organic matter is a vital parameter for making soil alive, because it improves different physical, biological and chemical properties (Hoyle et al., 2011). The organic matter varied from 2.07 to $6.53 \%$ with a mean of $4.20 \%$ (Table 4 ). The distribution of organic matter ranged from low to high, but medium status was prevalent (Figure 5). The study area, being high altitude northern sites of Nepal nearly all around year have low temperature (Figure 1). The low temperature reduces the rapid microbial degradation of organic substances; hence organic matter is optimum in the study area. Organic matter showed moderate variability $(28.80 \%)$ among the soil samples.

\section{Total Nitrogen}

The total nitrogen ranged from 0.10 to $0.23 \%$ with a mean of $0.16 \%$ (Table 4). The distribution of nitrogen varied from medium to high, whereas

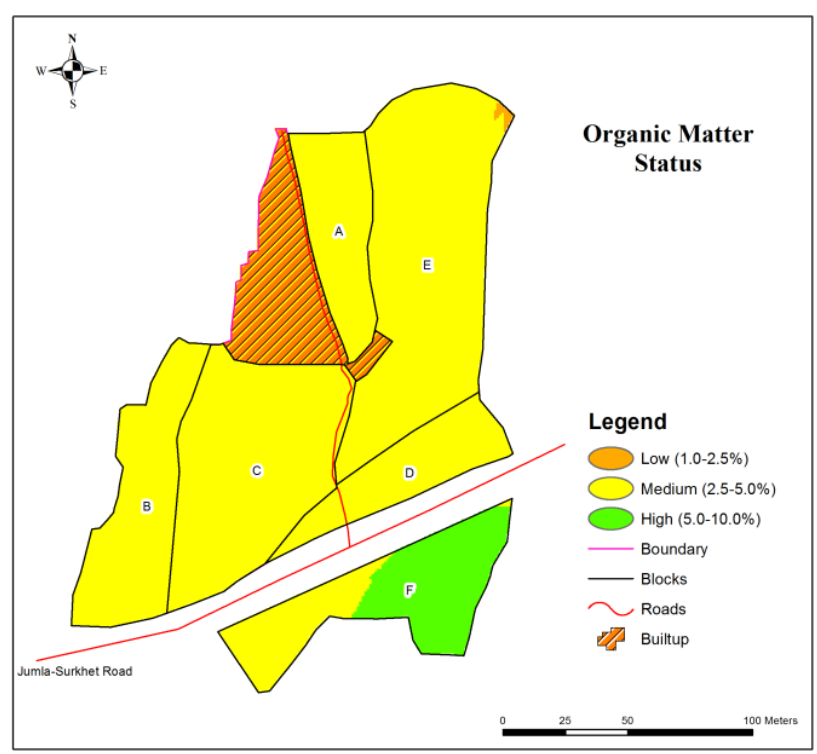

Figure 5. Spatial Distribution of Organic Matter in the Agricultural Research Station, Bijayanagar, Jumla, Nepal medium status is common (Figure 6). The optimum organic matter status as well as continuous application of nitrogenous fertilizer before starting of every crop might be the cause of optimum total nitrogen status. The area having medium and high distribution, $75 \%$ and $50 \%$, respectively of the total recommended nitrogen dose is requires for adequate supply of nitrogen for crops in the farm (Joshy and Deo, 1976). Total nitrogen showed low variability (21.81\%) among the soil samples. 


\section{Available Phosphorus}

Phosphorus is the second most limiting nutrient after nitrogen, and has negative impacts on crop yield if found to be deficient (Sharma et al., 2017). The available phosphorus varied from 64.20 to $257.20 \mathrm{mg} / \mathrm{kg}$ with a mean of $144 \mathrm{mg} / \mathrm{kg}$ (Table 4). The distribution of available phosphorus was very high singly (Figure 7 ). The higher content of available phosphorus in the farm might be due to the continuous application of phosphatic fertilizers for every crop without knowing phosphorus supplying capacity of soil. Being very high status, $40 \%$ of recommended phosphorus dose should be sufficient for the crops in the farm (Joshy and Deo, 1976). Available phosphorus showed moderate variability (33.64\%) among the soil samples.

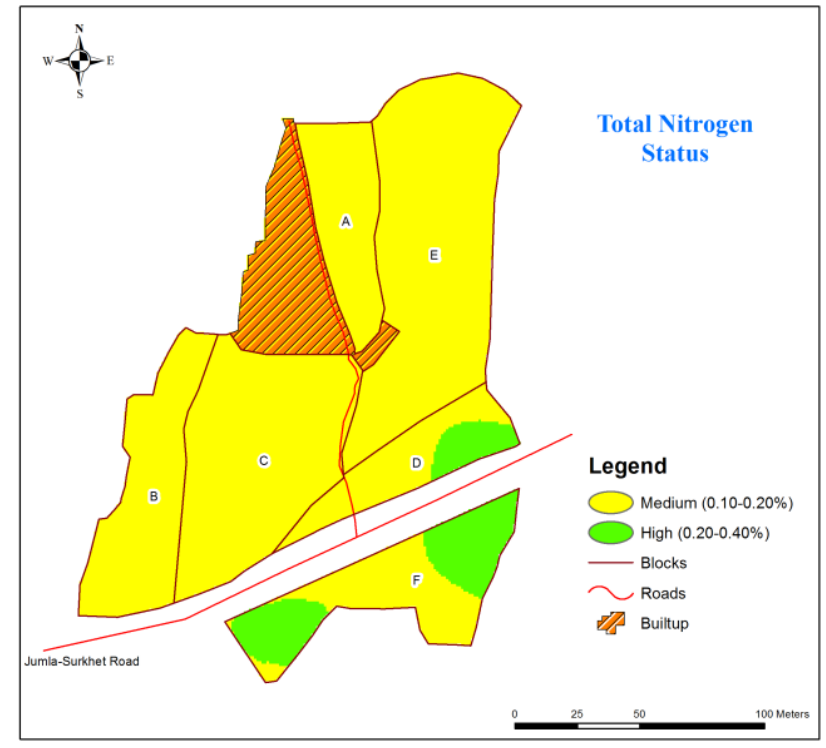

Figure 6. Spatial Distribution ofTotal Nitrogen in the Agricultural Research Station, Bijayanagar, Jumla, Nepal

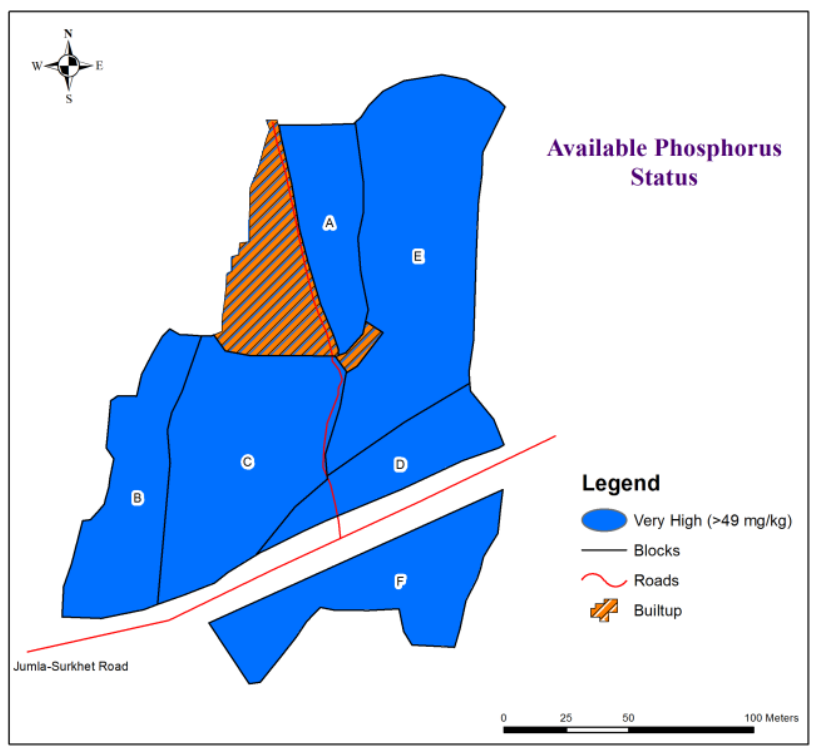

Figure 7. Spatial Distribution of Available Phosphorus in the Agricultural Research Station, Bijayanagar, Jumla, Nepal

\section{Available Potassium}

Potassium is one of the three major nutrients needed by plants, the others being nitrogen and phosphorus (Havlin et al., 2010). The available potassium varied from 40.4 to $255.2 \mathrm{mg} / \mathrm{kg}$ with a mean of $131.30 \mathrm{mg} / \mathrm{kg}$ (Table 4). The distribution of available potassium ranged from medium to high, but high is more (Figure 8). The different minerals such as muscovite, biotite, feldspars, orthoclase, microcline, mica etc. are major Kbearing minerals found in the earth (Sparks, 1987). The occurrence of their different minerals, optimum organic matter status andcomparative low content of sand separates among others might be the cause of satisfactory conditions of available potassium in the farm. The area having medium and high status, $60 \%$ and $40 \%$, respectively of recommended potassium dose should be sufficient for the crops in the farm (Joshy and Deo, 1976). Available potassium showed moderate variability (41.52\%) among the soil samples.

\section{Available Calcium}

Calcium is a secondary plant macronutrient, and is vital for running different living process in plants (Medvedev, 2005).The available calcium ranged from 1632 to $2880 \mathrm{mg} / \mathrm{kg}$ with a mean of $2166.9 \mathrm{mg} / \mathrm{kg}$ (Table 5). The distribution of available calcium was high solitary (Figure 9). The occurrence of nearly neutral soil $\mathrm{pH}$ in the majority of the sites might be the cause of high status of available calcium. Available calcium showed low variability (15.48\%) among the soil samples.

\section{Available Magnesium}

Magnesium is the second most abundant cation in living plant cells, and involved in many metabolic process (Tanol and Kobayashi, 2015). The available magnesium varied from 98.4 to $455.5 \mathrm{mg} / \mathrm{kg}$ with a mean of $267.6 \mathrm{mg} / \mathrm{kg}$ (Table 5). The distribution of available magnesium was solitary high (Figure 10). Similar to magnesium, occurrence of nearly neutral soil $\mathrm{pH}$ in the majority of the sites might be the cause of high status of available magnesium. Available magnesium showed moderate variability (43.48\%) among the soil samples. 


\section{Available Sulphur}

Sulfur is an essential nutrient for plant growth due to its presence in proteins, glutathione, phytochelatins, thioredoxins, chloroplast membrane lipids, and certain coenzymes and vitamins (Takahashi et al., 2011). The available sulphur ranged from 0.59 to $6.23 \mathrm{mg} / \mathrm{kg}$ with a mean of $1.56 \mathrm{mg} / \mathrm{kg}$ (Table 5).The distribution of available sulphur was very low merely (Figure 11). Khadka et al. $(2016,2017,2018)$ also reported very critical status of available sulphur in the different sites of Nepal. The intense cultivation of crops without application of sulphur containing fertilizer might be the cause of deficient status of available sulphur in the field. Being critical sulphur status, application at the rate of $15-30 \mathrm{~kg} \mathrm{~S} / \mathrm{ha}$ is mandatory for reducing sulphur deficiency stress for crops (Khatri-Chettri, 1991). During sulphur fertilizer application care should have to take in acidic inhibiting site, as they have acidity causing behavior. Available sulphur showed high variability (84.4\%) among the soil samples.

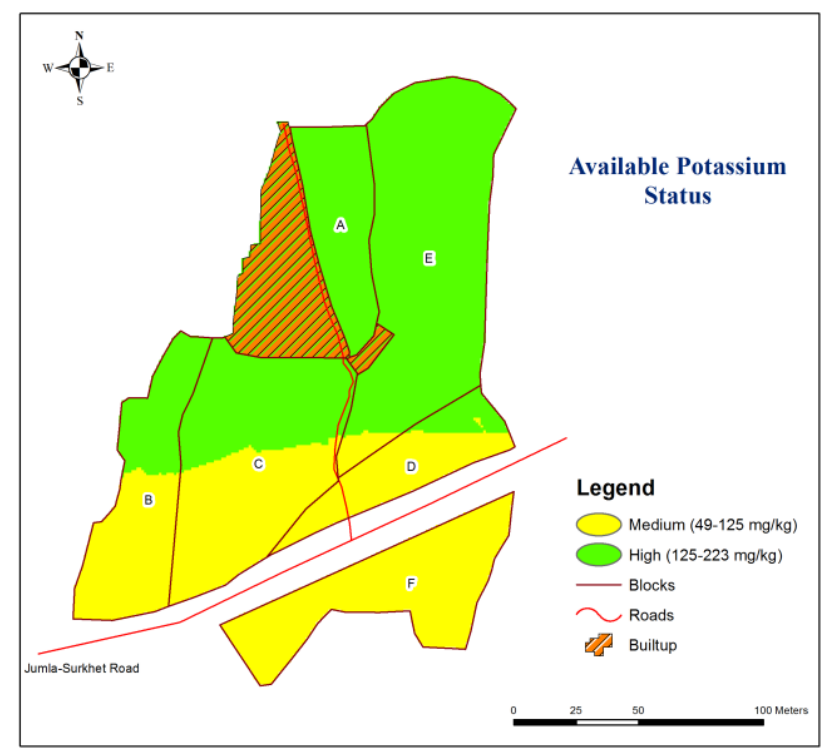

Figure 8. Spatial Distribution of Available Potassium in the Agricultural Research Station, Bijayanagar, Jumla, Nepal

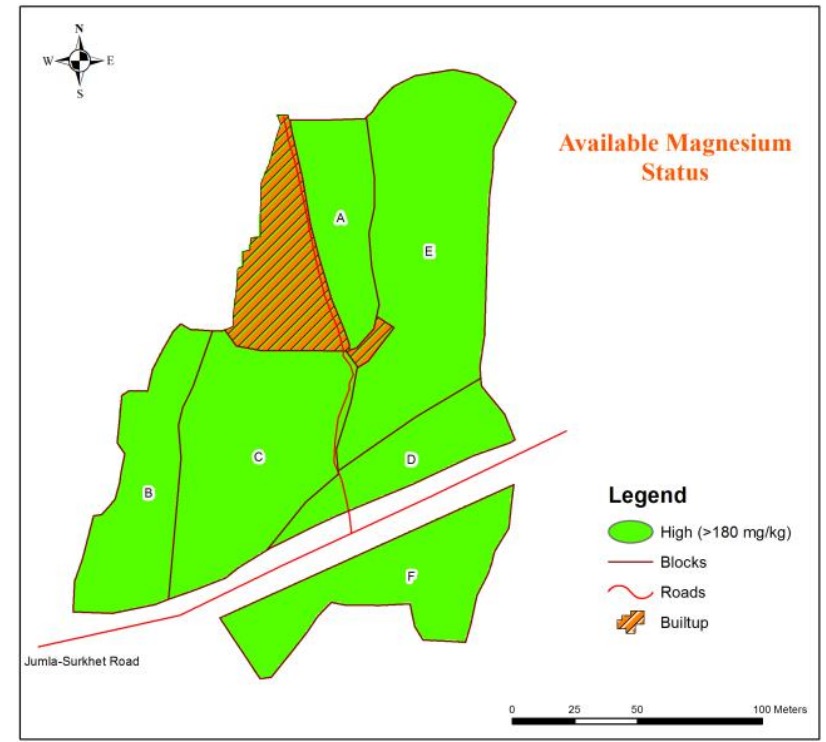

Figure 10. Spatial Distribution of Available Magnesium in the Agricultural Research Station, Bijayanagar, Jumla, Nepal

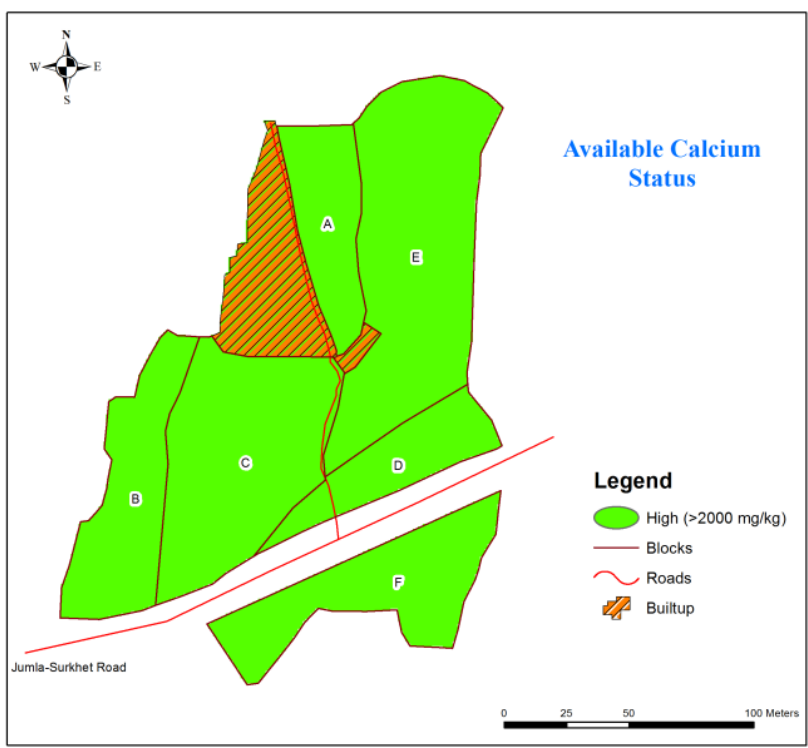

Figure 9. Spatial Distribution of Available Calcium in the Agricultural Research Station, Bijayanagar, Jumla, Nepal

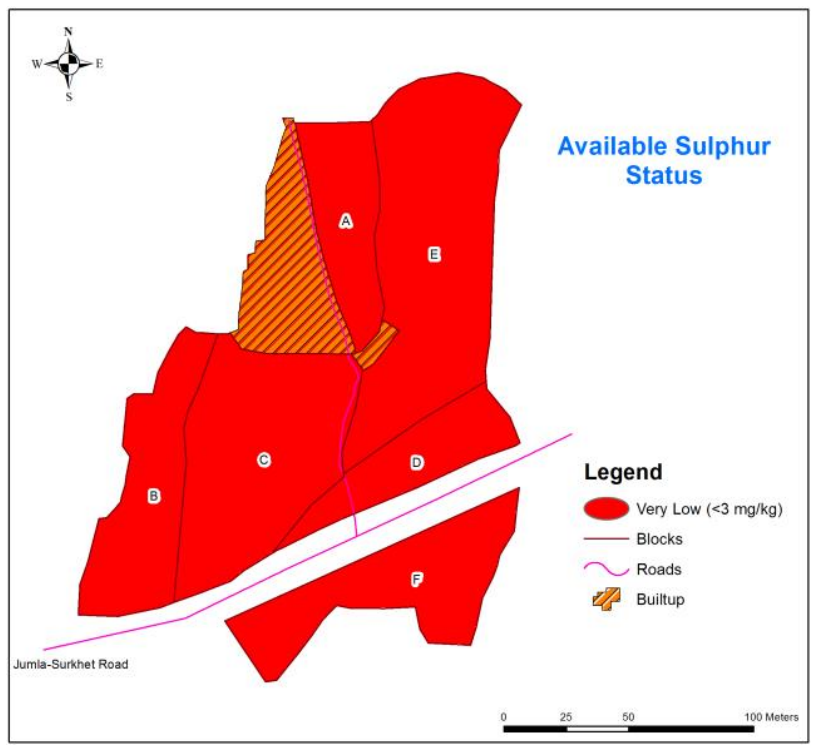

Figure 11. Spatial Distribution of Available Sulphur in the Agricultural Research Station, Bijayanagar, Jumla, Nepal 
Table 5. Soil Fertility Status of Agricultural Research Station, Bijayanagar, Jumla, Nepal

\begin{tabular}{lcccc}
\hline Descriptive & \multicolumn{4}{c}{ Soil Fertility Parameters } \\
\cline { 2 - 5 } Statistics & $\mathrm{Ca}, \mathrm{mg} / \mathrm{kg}$ & $\mathrm{Mg}, \mathrm{mg} / \mathrm{kg}$ & $\mathrm{Sg} / \mathrm{kg}$ & $\mathrm{B}, \mathrm{mg} / \mathrm{kg}$ \\
\hline Mean & 2166.9 & 267.6 & 0.31 & 0.25 \\
SEM & 79 & 27.4 & 1.31 & 0.03 \\
SD & 335.4 & 116.4 & 0.59 & 0.13 \\
Minimum & 1632 & 98.4 & 6.23 & 0.01 \\
Maximum & 2880 & 455.5 & 84.4 & 0.38 \\
CV\% & 15.48 & 43.48 & 53.44 \\
\hline
\end{tabular}

$\mathrm{SEM}=$ Standard error of the mean; $\mathrm{SD}=$ Standard deviation

\section{Available Boron}

Boron deficiency is documented as second most important micronutrient constraints after zinc in the world (Ahmad et al., 2012). The available boron ranged from 0.01 to $0.38 \mathrm{mg} / \mathrm{kg}$ with a mean of 0.25 $\mathrm{mg} / \mathrm{kg}$ (Table 5). The distribution of available boron was very low only (Figure 11). The very deficient status of available boron was also reported by Khadka et al. (2016, 2017, 2018) during their study in the different sites of Nepal. The intense cultivation of crops without application of boron containing fertilizer might be the cause of deficient status of available boron in the field. Being inadequate boron, application of $2-3 \mathrm{~kg} \mathrm{~B} / \mathrm{ha}$ is advisable for reducing boron deficiency stress for crops (Khatri-Chettri, 1991). Available boron showed high variability (53.44\%) among the soil samples.

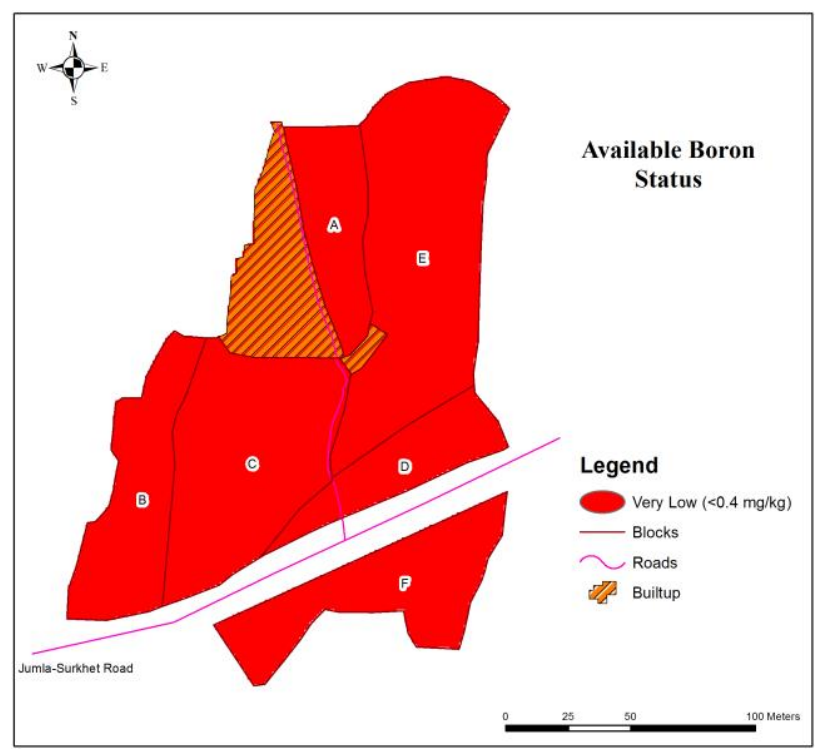

Figure 12.Spatial Distribution of Available Boron in the Agricultural Research Station, Bijayanagar, Jumla, Nepal

\section{Available Iron}

Iron is an important micronutrient in the life cycle of plant, and plays important role for their various metabolic process (Rout and Sahoo, 2015). The available iron varied from 15.9 to $300.5 \mathrm{mg} / \mathrm{kg}$ with a mean of $121.6 \mathrm{mg} / \mathrm{kg}$ (Table 6). The distribution of available iron ranged from very low to very high, although very high status was prevalent (Figure 13). Similar very high status was also determined by Khadka et al. (2016, 2017,2018 ) during their study in the different sites of Nepal. The occurrence of primary and secondary iron minerals such as hematite, olivine, siderite, goethite, magnetite etc. might be the cause of high content of available iron, because these are the major mineral containing iron element (Havlin et al., 2010). The high iron availability reduces the uptake of different nutrients such as $\mathrm{P}, \mathrm{K}, \mathrm{Mn}$ and $\mathrm{Zn}$; thus shows deficiency stress of these elements in the plants (Fageria et al., 2008). Therefore, proper care should be taken for reducing deficiency stress of these antagonistic elements. Available iron showed high variability $(80.94 \%)$ among the soil samples.

Table 6. Soil Fertility Status of Agricultural Research Station, Bijayanagar, Jumla, Nepal

\begin{tabular}{lcccc}
\hline & \multicolumn{4}{c}{ Soil Fertility Parameters } \\
\cline { 2 - 5 } Descriptive Statistics & Fe, mg/kg & Zn, mg/kg & Cu, mg/kg & Mn, mg/kg \\
\hline Mean & 121.6 & 2.93 & 5.59 & 5.55 \\
SEM & 23.2 & 0.44 & 0.64 & 0.88 \\
SD & 98.5 & 1.86 & 2.72 & 3.74 \\
Minimum & 15.9 & 1.12 & 2.58 & 1.46 \\
Maximum & 300.5 & 8.26 & 12.16 & 12.88 \\
CV\% & 80.94 & 63.57 & 48.64 & 67.31 \\
\hline
\end{tabular}

SEM=Standard error of the mean; SD=Standard deviation

\section{Available Zinc}

Zinc deficiency is a major micronutrient constraint for food production in every parts of the world and found positive response of their application in almost all crops (Welch, 2002). The available zinc varied from 1.12 to $8.26 \mathrm{mg} / \mathrm{kg}$ with a mean of $2.93 \mathrm{mg} / \mathrm{kg}$ (Table 6). The distribution of available zinc ranged from medium 
to high, while medium status was common (Figure 14). Available zinc showed high variability (63.57\%) among the soil samples.

\section{Available Copper}

Copper is an essential micronutrient for plant growth and development, although it is also potentially toxic (Yruela, 2005). The available copper ranged from 2.58 to $12.16 \mathrm{mg} / \mathrm{kg}$ with a mean of $5.59 \mathrm{mg} / \mathrm{kg}$ (Table 6). The distribution of available copper was very high only (Figure 15). The very high level of available copper may showed different kinds of toxic effects in the life cycles of plants. Reduced seed germination, inhibition of root and shoot growth, disturbance on photosynthetic apparatus and pigments etc. are the toxic effects of copper (Adrees et al., 2015). Being very high status of available copper in the soil, care should have to take during fungicide, pesticides, herbicides application in the field because these chemical already contains copper element (Husak, 2015). Available copper showed moderate variability (48.64\%) among the soil samples.

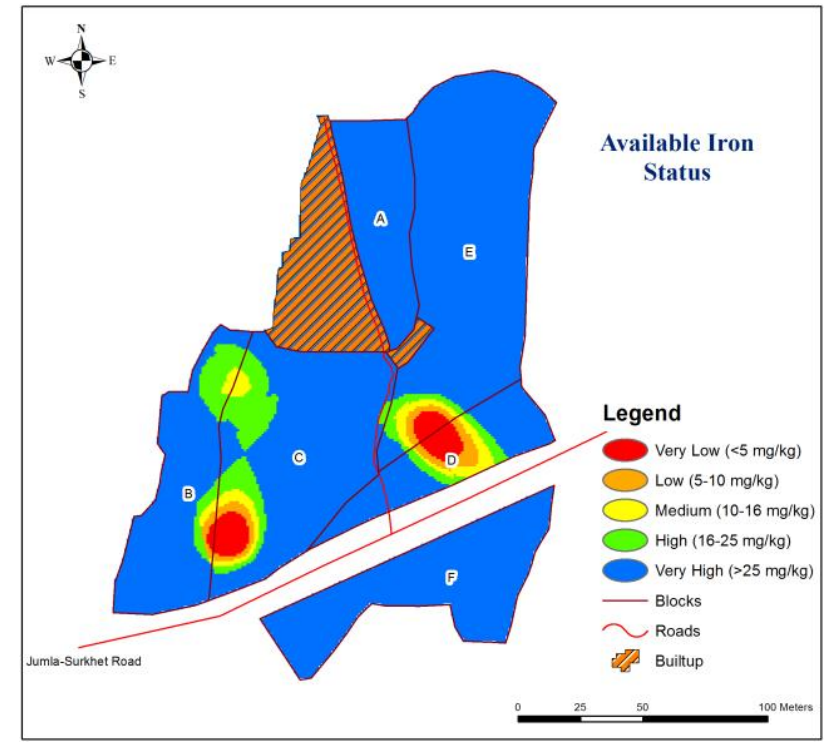

Figure 13. Spatial Distribution of Available Iron in the Agricultural Research Station, Bijayanagar, Jumla, Nepal

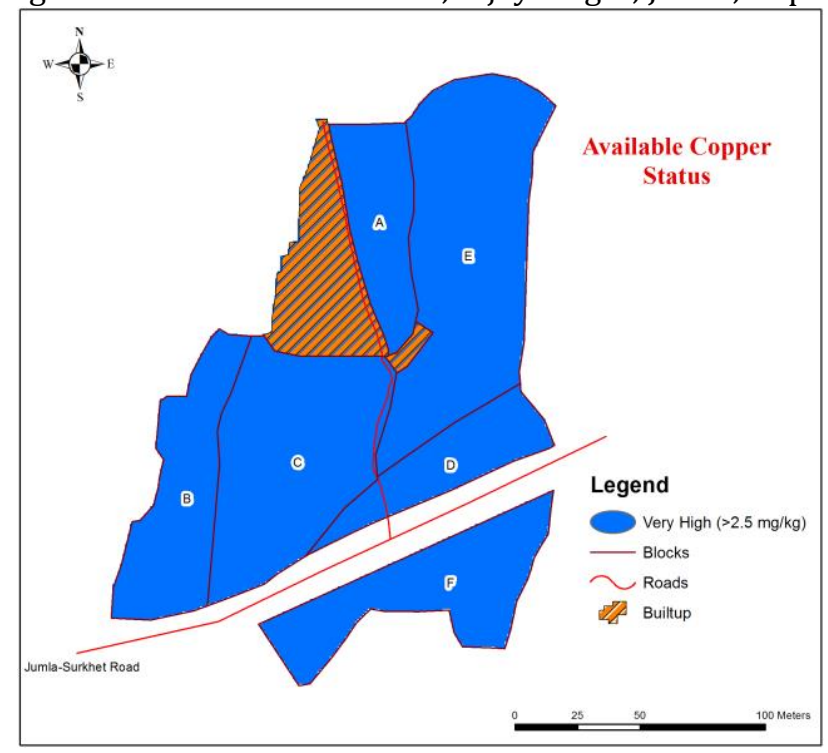

Figure 15. Spatial Distribution of Available Copper in the Agricultural Research Station, Bijayanagar, Jumla, Nepal

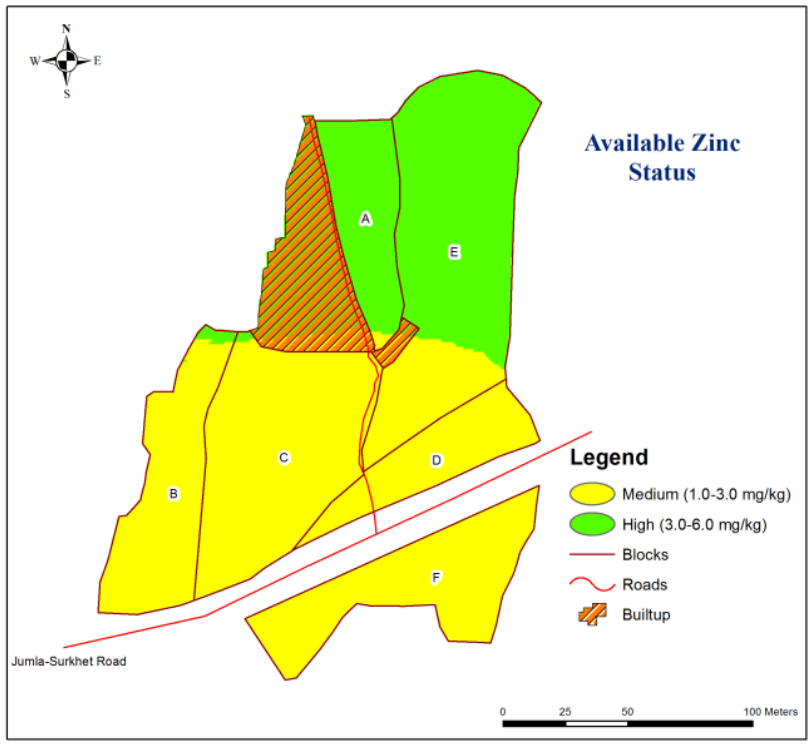

Figure 14. Spatial Distribution of Available Zinc in the Agricultural Research Station, Bijayanagar, Jumla, Nepal

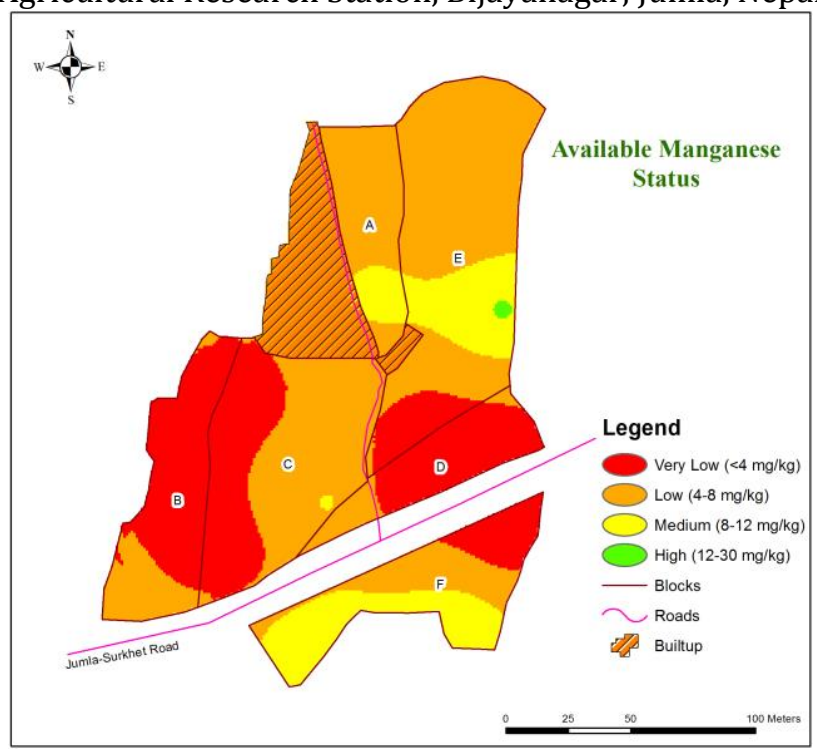

Figure 16. Spatial Distribution of Available Manganese in the Agricultural Research Station, Bijayanagar, Jumla, Nepal

\section{Available Manganese}

Manganese is also an important micronutrient for plants, prevailing in several metabolic process as photosynthetic and enzyme antioxidant-cofactor (Millaleo et al., 2010). The available manganese varied 1.48 to $12.88 \mathrm{mg} / \mathrm{kg}$ with a mean of $5.55 \mathrm{mg} / \mathrm{kg}$ (Table 6). The distribution of available manganese ranged from very low to high, whereas low status was common (Figure 16). Manganese mining due to intense cultivation 
of crops without application of manganese containing fertilizer might be the cause of deficient status of available manganese in the field. Moreover, difference in cropping system, farming practices and fertilization might be the cause of high spatial distribution of available manganese. Being inadequate available manganese, application of 8-16 kg Mn/ha is advisable for reducing manganese deficiency stress in plants (Khatri-Chettri, 1991). Available manganese showed high variability (67.31\%) among the soil samples.

Table 7. Nutrient indices of studied parameters of Agricultural Research Station, Bijayanagar, Jumla, Nepal

\begin{tabular}{|c|c|c|c|c|c|c|c|}
\hline \multirow[b]{2}{*}{ Parameters } & \multicolumn{5}{|c|}{$\%$ distribution of samples } & \multirow[b]{2}{*}{ Nutrient index } & \multirow[b]{2}{*}{ Remarks } \\
\hline & Very Low & Low & Medium & High & Very High & & \\
\hline $\mathrm{OM}$ & 0 & 11 & 61 & 20 & 0 & 2.17 & Medium \\
\hline $\mathrm{N}$ & 0 & 6 & 78 & 17 & 0 & 2.11 & Medium \\
\hline $\mathrm{P}_{2} \mathrm{O}_{5}$ & 0 & 0 & 0 & 0 & 100 & 3.00 & High \\
\hline $\mathrm{K}_{2} \mathrm{O}$ & 0 & 6 & 44 & 39 & 11 & 2.44 & High \\
\hline $\mathrm{Ca}$ & 0 & 0 & 28 & 72 & 0 & 2.72 & High \\
\hline $\mathrm{Mg}$ & 0 & 0 & 28 & 72 & 0 & 2.72 & High \\
\hline $\mathrm{S}$ & 94 & 6 & 0 & 0 & 0 & 1.00 & Low \\
\hline B & 100 & 0 & 0 & 0 & 0 & 1.00 & Low \\
\hline $\mathrm{Fe}$ & 0 & 0 & 6 & 11 & 83 & 2.94 & High \\
\hline $\mathrm{Zn}$ & 0 & 0 & 67 & 22 & 11 & 2.33 & Medium \\
\hline $\mathrm{Cu}$ & 0 & 0 & 0 & 0 & 100 & 3.00 & High \\
\hline $\mathrm{Mn}$ & 39 & 28 & 28 & 6 & 0 & 1.39 & Low \\
\hline
\end{tabular}

\section{Conclusion}

The determined soil test data can be used mainly in two aspects. First one is for sustainable soil management, while another for developing research strategyas being a farm of research station. The studied physical properties symbolize the current status is satisfactory for agricultural purpose. The organic matter is optimum in the farm. For maintaining existing status, current organic matter management practice should be continued. The fertilizer should be applied for each crops based on the determined nutrient distribution status shown in the prepared maps of farm. The plants may suffer from deficiency stress of low, and toxicity stress of very high status of nutrients. The proper care should be taken for such types of nutrients. For enhancing research efficacy of the station, future research strategy should be built based on the determined soil fertility status and their distribution. This farm can be used as a pocket research site, especially for high altitude iron and copper toxicity as well as sulphur and boron deficiency tolerant study.

\section{Acknowledgements}

The authors would like to acknowledge Nepal Agricultural Research Council for funding this research. We are very much thankful to Agricultural Research Station, Bijayanagar, Jumla, Nepal for their cooperation. Similarly, support of the Soil Science Division, Khumaltar for providing laboratory facilities to analyze the soil samples and preparation of soil fertility maps as well as other technical support is highly acclaimed.

\section{References}

Acharya, A.K., Paudel, M. P., Wasti, P.C., Sharma, R.D., Dhital, S., 2018. Status Report on Food and Nutrition Security in Nepal. Ministry of Agriculture, Land Management and Cooperatives, Kathmandu, Nepal.

Adrees, M., Ali, S., Rizwan,M., Ibrahim, M., Abbas, F., Farid, M., Bharwana, S.A., 2015. The effect of excess copper on growth and physiology of important food crops: a review. Environmental Science and Pollution Research 22(11): 8148-8162.

Ahmad, W., Zia, M.H., Malhi, S. S., Niaz, A., Saifullah, 2012. Boron Deficiency in soils and crops: a review. In: Crop Plant. Goyal, A. (Ed.). IntechOpen.

ARS, 2017. Annual Report 2073/74 (2017). Agriculture Research Station, NARC, Bijayanagar, Jumla, Nepal.

Aweto, A.0., 1982. Variability of upper slope soils developed under sandstones in South-western Nigeria. Georgian Journal 25: 27-37.

Baumann, K., Schöning, I., Schrumpf, M., Ellerbrock, R.H., Leinweber, P., 2016. Rapid assessment of soil organic matter: Soil color analysis and Fourier transform infrared spectroscopy. Geoderma 278: 49-57.

Berger, K.C., Truog, E., 1939. Boron determination in soils and plants. Industrial and Engineering Chemistry Analytical Edition 11(10): 540-545. 
Berry, W., Ketterings, Q., Antes, S., Page, S., Russell Anelli, J., Rao, R., DeGloria, S., 2007. Soil Texture. Agronomy Fact Sheet Series, Fact Sheet 29. Cornell University Cooperative Extension. Available at [Access date: 19.08.2018]: http://nmsp.cals.cornell.edu/publications/factsheets/factsheet29.pdf

Bouyoucos, G.J., 1962. Hydrometer method improved for making particle size analyses of soils. Agronomy Journal 54(5): 464-465.

Brady, N. C., Weil, R., 2002. The nature and properties of soils. 13 ${ }^{\text {th }}$ Edition, Pearson Education, New Jersey. USA. 980p.

Bremner, J.M., Mulvaney, C.S., 1982. Nitrogen total. In: Methods of soil analysis. Part 2 Chemical and microbiological properties. 2nd edition. Page, A.L. (Ed.). American Society of Agronomy, No. 9, Madison, WI, USA. pp. 595-624.

Cambardella, C.A., Karlen, D.L., 1999. Spatial analysis of soil fertility parameters. Precision Agriculture 1(1): 5-14.

Chaudhari, P. R., Ahire, D. V., Ahire, V. D., Chkravarty, M., Maity, S., 2013. Soil bulk density as related to soil texture, organic matter content and available total nutrients of Coimbatore soil. International Journal of Scientific and Research Publications 3(2): 1-8.

El Mahi, Y.E., Ibrahim, I.S., Abdel Magid, H.M., Eltilib, A.M.A., 1987. A simple method for the estimation of calcium and magnesium carbonates in soils. Soil Science Society of America Journal 51(5): 1152-1155.

Fageria, N.K., Santos, A.B., Filho, M.P., Guimaries, C.M., 2008. Iron toxicity in lowland rice. Journal of Plant Nutrition 31(9): 1676-1697.

Havlin, H.L., Beaton, J.D., Tisdale, S.L., Nelson, W.L., 2010. Soil Fertility and Fertilizers: An Introduction to Nutrient Management. $7^{\text {th }}$ Edition, PHI Learning Private Limited, New Delhi. India. 516p.

Hoyle, F.C., Baldock, J.A., Murphy, D.V., 2011. Soil organic carbon - role in rainfed farming systems: with particular reference to Australian conditions. In: Rainfed farming systems. Tow, P., Cooper, I., Partridge, I., Birch, C., (Eds.). Springer, New York, USA. pp. 339-361.

Huang, B., Sun, W., Zhao, Y., Zhu, J., Yang, R., Zou, Z., Ding, F., Su, J., 2007. Temporal and spatial variability of soil organic matter and total nitrogen in an agricultural ecosystem as affected by farming practices. Geoderma 139(3-4):336345.

Husak, V., 2015. Copper and copper containing pesticides: metabolism, toxicity and oxidative stress. Journal of Vasyl Stefanyk Precarpathian National University 2(1): 38-50.

Jackson, M.L., 1973. Soil chemical analysis (Indian Edition). Prentice Hall of India Pvt. Ltd., New Delhi, India.

Jones, Jr, J.B., 2012. Plant nutrition and soil fertility manual. $2^{\text {nd }}$ Edition, CRC press. New York, USA. 299p.

Joshy, D., Deo, G.P., 1976. Fertilizers Recommendations for Major crops of Nepal. Division of Soil Science and Agricultural Chemistry, Department of Agriculture, HMG/Nepal.

Keen, B.A., Raczkowski, H., 1921. The relation between clay content and certain physical properties of soil. The Journal of Agricultural Sciences 11(4): 441-449.

Khadka, D., Lamichhane, S., Bhurer, K.P., Chaudhary, J.N., Ali, M.F., Lakhe, L., 2018. Soil Fertility Assessment and Mapping of Regional Agricultural Research Station, Parwanipur, Bara, Nepal. Journal of Nepal Agricultural Research Council 4(28): 33-47.

Khadka, D., Lamichhane, S., Malla, R., Joshi, S., 2016. Assessment of soil fertility status of oilseed research program, Nawalpur, Sarlahi, Nepal. International Journal of Advanced Research 4(6): 1472-1483.

Khadka, D., Lamichhane, S., Tiwari, D.N., Mishra, K., 2017. Assessment of soil fertility status of National Rice Research Program, Hardinath, Dhanusha, Nepal. International Journal of Agricultural and Environmental Research 3(1): 86105.

Khatri-Chettri, T.B., 1991. Introduction to Soils and Soil fertility. Tribhuvan University Institute of Agricultural and Animal Science, Rampur, Chitwan, Nepal. 233p.

Lindsay, W.L., Norvell, W.A., 1978. Development of a DTPA soil test for zinc, iron, manganese, and copper. Soil Science Society of America Journal 42(3): 421-428.

Liu, Z.P., Shao, M.A., Wang, Y.Q., 2013. Spatial patterns of soil total nitrogen and soil total phosphorus across the entire Loess Plateau region of China. Geoderma 197-198: 67-78.

Mandal, A.K., Sharma, R.C., 2009. Computerized database of salt affected soils for Peninsular India using GIS. Geocarto International 24(1): 64-85.

Medvedev, S.S., 2005. Calcium signaling system in plants. Russian Journal of Plant Physiology 52(2): 249-270.

Millaleo, R., Reyes-Díaz, M.,Ivanov, A.G., Mora, M.L., Alberdi, M., 2010. Manganese as essential and toxic element for plants: transport, accumulation and resistance mechanisms. Journal of Soil Science and Plant Nutrition 10(4): 470-481.

Mishra, A., Das,D., Saren, S., 2013. Preparation of GPS and GIS based soil fertility maps for Khurda district, Odisha. Indian Agriculturist 57(1): 11-20.

Munsell., 2009. Standard soil colour charts. Munsell color company, Inc. Baltimore, Maryland, USA.

Olsen, S.R., Cole, C.V., Watanabe, F.S., Dean, L.A., 1954. Estimation of available phosphorus in soils by extraction with sodium bicarbonate. U.S. Department of Agriculture, Circular No 939, USA, 19p.

Pagliai, M., Vignozzi, N., 2002. Image analysis and microscopic techniques to characterize soil pore system. In: Physical Methods in Agriculture. Blahovec, J., Kutilek, M., (Eds.). Kluwer Academic Publishers, New York. USA. p. 13-38.

Panda, S.C., 2010. Soil Management and Organic Farming. Agrobios, Bharat Printing Press, Jodhpur, India. 462p. 
Ramamoorthy, B., Bajaj, J.C., 1969. Available nitrogen, phosphorus and potassium status of Indian soils. Fertilizer News 14: 25-36.

Rout, G. R., Sahoo, S., 2015. Role of iron in plant growth and metabolism. Reviews in Agricultural Science 3(1): 1-24.

Sharma, L.K., Bali, S.K., Zaeen, A.A., 2017. A case study of potential reasons of increased soil phosphorus levels in the Northeast United States. Agronomy 7(4): 85.

Song, G., Zhang,L. Wang,K., Fang, M., 2013. Spatial simulation of soil attribute based on principles of soil science. $21^{\text {st }}$ International Conference on Geoinformatics. 20-22 June 2013. Kaifeng, China.

Sparks, D.L., 1987. Potassium dynamics in soils. In: Advances in Soil Science. Stewart, B.A. (Ed.) Vol 6, Springer, New York, USA. pp. 1- 63.

Takahashi, H., Kopriva, S., Giordano, M., Saito, K., Hell, R., 2011. Sulfur assimilation in photosynthetic organisms: molecular functions and regulations of transporters and assimilatory enzymes. Annual Review of Plant Biology 62: 157-184.

Tanol, K., Kobayashi, N.I., 2015. Leaf senescence by magnesium deficiency. Plants 4(4): 756-772.

Verma, B.C., Swaminathan, K., Sud, K.C., 1977. An improved turbidimetric procedure for the determination of sulphate in plants and soils. Talanta 24(1): 49-50.

Walkley, A.J., Black, I.A., 1934. Estimation of soil organic carbon by the chromic acid titration method. Soil Science 37(1): 29-38.

Weindorf, D.C., Zhu, Y., 2010. Spatial variability of soil properties at Capulin volcano, New Mexico, USA: Implications for sampling strategy. Pedosphere 20(2): 185-197.

Welch, R.M., 2002. The impact of mineral nutrients in food crops on global human health. Plant and Soil 247(1): 83-90.

Yruela, I., 2005. Copper in plants. Brazilian Journal of Plant Physiology 17(1): 145-156. 